\title{
Reframing Teacher Education: \\ Preparing Teachers for Inclusive Education
}

\author{
Jennifer A. Kurth \\ University of Kansas \\ Jean Ann Foley \\ Northern Arizona University
}

Citation: Kurth, J. A., \& Foley, J. A. (2014). Reframing teacher preparation: Preparing teachers for inclusive education. Inclusion, 2(4), 286-300. doi: 10.1352/2326-6988-

2.4.286 


\begin{abstract}
Inclusive education is increasingly common in K-12 schools, yet teacher preparation for inclusive education has been lagging. In the present study, interviews of teacher candidates, mentor teachers, university faculty, and fieldwork supervisors were completed to determine experiences of, and preparation for, inclusive education. Results indicate that teacher candidates received very mixed, and often contradictory, messages about inclusive education in their coursework and fieldwork experiences. Recommendations for building capacity for inclusive fieldwork and inclusive teacher preparation are proposed. Further, the need for teacher educators to reframe teacher preparation, from the traditional model of preparing teachers for largely segregated roles, to providing the skills and techniques necessary for working and succeeding in inclusive settings, is discussed.
\end{abstract}




\section{Reframing Teacher Education: Preparing Teachers for Inclusive Education}

Over the past several decades, teacher preparation programs have witnessed an increasing trend of educating students with disabilities in inclusive settings (Data Accountability Center, 2008). Inclusive education is defined here as full membership in a general education class with the range of supports and services provided for a student to be successful in that setting. It is contrasted with mainstreaming, which implies students visit a general education setting for only certain activities during a school day.

However, the trend towards educating students with disabilities in general education settings has not been matched in teacher preparation programs, which continue to primarily prepare teachers for work in self-contained settings. There is a risk that, when higher education faculty do prepare teacher candidates for work in inclusive settings, the instruction is translated as creating a positive disposition toward inclusive education rather than as a commitment to equity in education supported by a set of skills and knowledge. Reframing teacher preparation for inclusive settings requires a critical understanding of exclusion united with instructional knowledge and skills for inclusive education.

This paper first provides a brief literature review to highlight some persistent issues and trends in inclusive teacher preparation. Next, the methodology and design of the study are explained. Findings, limitations, and discussion follow with recommendations for reframing teacher preparation.

\section{Persistent Issues and Trends in Inclusive Teacher Preparation}

A number of persistent issues and trends in inclusive teacher preparation have been identified that likely impact the widespread implementation of inclusive practices, 
including: dispositions for inclusive education, social justice issues, the range of skills needed to implement quality inclusive practices, institutes of higher education (IHE) preparation for inclusive education, and difficulties in finding appropriate fieldwork settings.

Dispositions. In a survey of pre-service general education teachers, Cook (2002) found that teacher candidates self-identified as having positive dispositions and personal characteristics towards inclusion, but lacked instructional knowledge and skills for inclusive education. Having a positive disposition to include all students is a worthwhile attitude, but it does little to disrupt exclusionary practices that isolate students with disabilities. Developing an understanding of inclusive education as a link to social justice for all students can strengthen the agency for seeking and applying the skills and knowledge required for work in inclusive settings. For this paper, social justice is defined as "full participation of all groups in a society that is mutually shaped to meet their needs" (Adams, Bell, \& Griffin, 1997). Using social justice as a framework for inclusive education provides a holistic approach that focuses on "educating all children, to the greatest possible extent, together in a regular classroom setting" (Tompkins \& Deloney, 2013, p. 3).

Social justice. Strong arguments for inclusive education come from a philosophical base stressing ideals related to freedom and equity. From this perspective difference is seen as a plus for society in that all benefit from understanding different perspectives, abilities, culture, and the like. Stiker (1997) explained,

We must then inscribe in our cultural models a view of difference as the law of the real. It is a matter of stating and restating, first of all to children throughout 
their education, that it is inscribed in the human universe to value the differences

it engenders and of which it is also a product (p. 12).

This cultural view goes beyond a positive attitude and moves toward an epistemology that re-centers "education on issues of social justice, that is, on a social movement against oppression" Kumashiro, 2004, p. xxiv). Besides possessing a philosophy that desires to disrupt issues of oppression, particular skills for inclusive settings need to be taught.

Skills. In fact, there is a wide range of skills and knowledge required for work in inclusive settings; these skills are qualitatively different from the skills needed for work in segregated settings. For example, inclusive educators must be knowledgeable of core content areas, characteristics of students with disabilities, special education processes and have understandings of how to differentiate curriculum and promote classroom management for effective learning (Allday, Neilsen-Gatti, \& Hudson, 2013). However, in a review of over 30 years of teacher perception regarding inclusive education, Scruggs and Mastropieri (1996) found that of the over 10,000 teachers surveyed, fewer than one third reported they were skilled to implement inclusive education successfully; there is no indication that teacher confidence has improved since then (e.g., Boyle, Topping, \& Jindal-Snape, 2013). This suggests traditional teacher preparation in special education is not meeting the needs of inclusive educators, and must have a focus on preparing teachers in a different set of skills and knowledge than is typical of teacher preparation programs.

IHE preparation. While there have been increasing rates of inclusive education in K-12 schools, IHEs have generally not kept up with this trend. Instead, inclusive education has been implemented in the field, but has not been a part of teacher 
preparation (Gut, Oswald, Leal, Frederiksen, \& Gustafson, 2003). Some teacher preparation programs have started to require general education teachers complete a special education course as part of their preparation (e.g., Cook, 2002). Yet this is by no means sufficient preparation. Some innovative teacher preparation programs are turning to unified and infused programs of teacher preparation. These programs break down the traditional divides between general and special education (Frattura \& Topinka, 2006; Young, 2011) by infusing content related to inclusive education into existing courses (Cameron \& Cook, 2007), providing dual-certification in general and special education (Oyler, 2011), and even co-teaching methods courses (Ashby, 2012). While these programs are promising, they are too often plagued by the same issues of traditional teacher preparation programs: faculty rarely engage in cross-articulation and co-teaching (Harvey, Yssel, Bauserman, \& Merbler, 2010), and students may develop positive dispositions, but not always the skills needed to translate these beliefs into practice (Cameron \& Cook, 2007). In a recent review of elementary teacher preparation program coursework, Allday and colleagues (2013) suggested many teacher preparation programs lack important elements of teacher preparation for inclusive education and dedicate only $7-10 \%$ of their coursework to issues of inclusive education, focusing instead on characteristics of disabilities and classroom management. Also in regards to traditional teacher preparation programs, there is a dominant view to maintain the status quo. Kumashiro (2009) notes,

Common and commonsensical notions of "real" or "good" teaching do not involve challenging oppression and can actually help to perpetuate rather than change the oppressive status quo of schools and society... Traditionally, teacher education programs have contributed to this problem by not significantly 
troubling the ways that dominating views and practices of "good" teachers contribute to oppression and hinder anti-oppressive change (Kumashiro, 2009, p. 1).

There is an ethos embedded in the teaching profession to adapt to current practices rather than question the consequences of possible inequity involved in those practices. For example, courses in teaching methods traditionally focus on how-to classroom procedures without considering the contexts of individual students including culture, race, gender and the dispositions of all students. This lack of consideration can strengthen a perspective that places the needs of the dominant over the needs of disenfranchised students. When context is disengaged from practice, a false sense of 'neutrality' or objectivity is created and the responsibility to question the effects of teaching methods in terms of equity and belonging in the classroom community is minimized.

Fieldwork settings. A number of challenges exist, then, to preparing teachers for inclusive education. A significant challenge in translating beliefs into practice is that, too often, teacher candidates' experiences in schools do not reflect the inclusive values and practices espoused by IHEs (Dotger \& Ashby, 2010). There is then a significant and troubling disconnect between what teacher candidates are taught and common practices in the field of special education (Gehrke \& Cocchiarella, 2013). Teacher candidates report an appreciation for IHE instructors who can provide real world, personal experiences about inclusive education, particularly when the teacher candidates did not have opportunities themselves to experience inclusive education in their fieldwork (Gehrke \& Cocchiarella, 2013). However, it is posited that it is likely few IHE faculty members have sufficient experience themselves teaching and working in inclusive settings, as quality inclusive settings continue to be a relative rarity. 
An important aspect of a teacher preparation program is the fieldwork experience teacher candidates engage in prior to certification (Hennissen, Crasborn, Brouwer, Korthhagen, \& Bergen, 2011). These fieldwork courses provide students with opportunities to develop teaching skills, gain real-world experience, and receive feedback from field-based educators (referred to here as mentor teachers) and university faculty. Being in the classroom setting can also supply the pre-service teacher with experience and observable data to reflect on issues associated with inclusive education (Voss \& Bufkin, 2011). Mentor teachers are further important in teaching the necessary skills for teacher candidates who can enter the profession and have strong beliefs in their own ability to be successful teachers (Clifford \& Green, 1996).

Given the need for inclusive teacher preparation, it is important to understand the full experiences and contexts teacher candidates experience in their preparation, along with the different messages they are taught about inclusive education from various sources during their pre-service preparation. The purpose of this research is to describe the teacher preparation experience for undergraduate students gaining certification in elementary and special education by examining perceptions towards inclusive education through multiple lenses. Teacher candidates, IHE fieldwork supervisors, IHE faculty, and mentor teachers (also known as field-based educators) were interviewed to understand how each of these groups defines and implements inclusive education. The following research questions are addressed: (1) How do stakeholders in inclusive teacher education define inclusive education? (2) Do fieldwork settings demonstrate inclusive practices as defined by these stakeholders?

\section{Method}




\section{Program Description and Context}

This project investigated the messages about inclusive education as conveyed in a teacher preparation dual-degree program. This teacher preparation program, known as the Praxis Partnership, is an intensive 3-semester cohort undergraduate program. The program exists at a teaching university in the American southwest. This IHE is situated in a rural area in a community of nearly 70,000 , and is a hub for smaller communities in the area. Nearly $20 \%$ of population lives below the poverty line. The nearest major metropolitan area is approximately 150 miles away. Praxis students (referred to here as teacher candidates) applied for the program in their junior year of university, and upon admittance were provided an education focusing on "theory into practice." This is demonstrated with more fieldwork learning and supervision than traditional students at this IHE, relationships with professional educators (mentor teachers), and support from program fieldwork supervisors. Specifically, traditional undergraduate students at this university enroll in a 40- hour fieldwork course for one semester (averaging about 3 hours per week in fieldwork for one total semester), whereas Praxis teacher candidates spent about 30 hours per week for three semesters in fieldwork experiences. These fieldwork experiences were in elementary and special education placements, ranging from kindergarten through high school settings. In addition to having more experience in classrooms, Praxis teacher candidates had mentorship from two IHE fieldwork supervisors (one who specialized in elementary education, and the other specialized in special education). These fieldwork supervisors provided mentorship and supervision to students in their fieldwork settings on average once per week. The fieldwork supervisors 
also led monthly seminars to discuss issues in fieldwork, and coordinated fieldwork placements for all Praxis Partnership students.

The dual major in special education at this university prepares students to become certified in special education and elementary education. A total of 83 credit hours are required for the major, which includes four special education and seven elementary education courses. This major is typically completed in four years (resulting in a bachelor's degree in education). The special education courses include courses in assessment, classroom (behavior) management, special education instructional methods, and student teaching. The elementary education courses include methods of teaching mathematics, science, and social studies, two courses on teaching literacy, a course on elementary curriculum, and student teaching. The university states teacher candidates must demonstrate content knowledge, pedagogical knowledge and skills, and professional knowledge to be eligible to enter student teaching. It is not clear from the course descriptions how extensively inclusive education is emphasized in the special or elementary education courses, although IHE faculty report inclusive education is incorporated into each course. Upon successful completion of all coursework and student teaching, teacher candidates are eligible to take the state teaching exam for licensure in special and elementary education.

Teacher candidates enrolled in this program were undergraduates in this dualmajor program in elementary and special education. These candidates were in their final year (generally, their $4^{\text {th }}$ year) of the undergraduate degree program at the time of this study. There were a total of 23 candidates in the cohort, all of whom were female, and all were between the ages of 20-24 years old at the time of the study. 
In addition to the fieldwork supervisors for the Praxis program, teacher candidates interacted with a variety of mentor teachers. These mentor teachers, sometimes referred to as field-based educators, were professional educators who "hosted" the teacher candidates in their classrooms, providing them with space and support to develop their teaching skills in K-12 special and general education settings. Mentor teachers are fully certified in their subject matter, and agree to work with the IHE and teacher candidates to support their professional growth. The IHE and school district have an agreement in that mentor teachers earn a small stipend in exchange for supporting teacher candidates. There are no formal requirements, other than certification, that mentor teachers must meet. Similarly, the IHE has no formal procedures for selecting mentor teachers. The fieldwork supervisors simply contact all teachers who are fully certified and ask them if they would be willing to support student teachers. Once a mentor teacher agrees, the school administrator must approve the request. The Praxis program was designed so teacher candidates spent the first eight-weeks of each semester in one classroom, and then changed fieldwork locations for the second eight-weeks of the semester. Therefore, over the course of the three-semester program, teacher candidates had fieldwork experience in six classrooms with six mentor teachers.

Finally, teacher candidates interacted with IHE faculty who taught undergraduate courses in general and special education. The teacher candidates in the Praxis Partnership completed on average 18 credit hours of coursework each semester. At the time of the study, teacher candidates were enrolled in coursework related to bilingual/multicultural education, classroom management, literacy instruction, technology in classrooms, and fieldwork. 
It is also important to describe the special education service delivery models in the school district where teacher candidates were placed. The school district historically had a traditional special education model, in which resource rooms and self-contained classrooms existed at the elementary and secondary levels for students with disabilities. This remained the practice of the host school district until the year of this study. The summer before the start of the school year, all elementary school teachers were urged to become dually certified in elementary and special education, or risk being laid off. The school district was eliminating separate resource rooms and special education teachers at the elementary level as a cost-savings measure. Going forward, all elementary school teachers were to become dually certified so they could act as general education teachers and special education teachers and case managers. Students receiving special education services were then clustered into the classrooms taught by dually certified teachers, to the greatest extent possible. At times, however, a classroom teacher had students on her special education caseload who were not in her classroom; and, due to the constraints of teaching general education, it was not feasible in most situations for that teacher to directly support or even provide meaningful consultation to the child's teacher. It is important to note that this change was for high-incidence special education programs only, and only at the elementary school levels. Self-contained classrooms for students with emotional behavioral disorders and low-incidence disabilities were maintained, and there were no changes at the secondary schools. The Individuals with Disabilities Education Improvement Act (IDEA; 2004) defines low-incidence disabilities as hearing or vision impairments, significant cognitive impairment, and any other impairment for which a small number of personnel with highly specialized skills and knowledge are 
needed (20 U.S.C. § 1400 Sec. 662(c)(3)). Low-incidence disabilities typically include less frequent and more "severe" disabilities, such as multiple disabilities, whereas highincidence disabilities are more frequently occurring in the school population and include disability categories such as learning disability or speech-language disorders.

Teachers in this district who took on this dual-role of special and general educator received a stipend for this added duty. However, as a result of these drastic changes and some of the turmoil the changes created in terms of teacher workload and the composition of classes, there was discord in the district. Teacher candidates had fieldwork experiences divided evenly between high-incidence and low-incidence special education, and general education. It is important to note that while the practices of this district are certainly troubling, and do not reflect best practices or quality inclusive practices, the rural nature of the IHE prohibited most students from completing fieldwork anywhere else.

\section{Participants, Collection Methods, and Analysis}

Interviews were completed to understand consistency in message about inclusive education within this teacher preparation program. Interviews with 11 teacher candidates out of a total of 23, 6 out of $9 \mathrm{IHE}$ faculty members (4 faculty members representing general education, 2 representing special education), both (2) IHE fieldwork supervisors, and 11 out of 16 mentor teachers ( 7 representing general education, 4 representing special education) were completed. The authors made arrangements with the Praxis supervisors to visit a class, explain the research, and invite all teacher candidates to participate. Those students who were interested in participating signed a list and provided contact information. These students were then contacted by e-mail to schedule interview times. 
IHE faculty members/fieldwork supervisors and mentor teachers were contacted via email from lists provided by the IHE fieldwork supervisors. These interviews were completed on the IHE campus or in the classrooms of teachers. Interviews were typically completed in 30-60 minutes, and were recorded, following guidelines from the human subjects protection board at the IHE. These recordings were then transcribed, and open coding was used to identify themes (Strauss \& Corbin, 1990). Each author examined the data for patterns in phrases and descriptors related to inclusion. Once the individual analyses were completed, comparisons of results were made and themes were created to classify similar responses. For further inter-observer reliability, a graduate assistant in education analyzed the data and independently recorded patterns and themes. Any disagreements were discussed and consensus reached. The interview data reported here is part of a larger study of teaching for social justice; for purposes of this study, only interview questions related to inclusive education are discussed.

\section{Results}

The results are presented for two interview questions related to inclusive education and the research questions for the current study: how stakeholders define inclusive education and then offering an example of inclusive education, as they defined it, being implemented in the fieldwork setting.

\section{Defining Inclusive education}

All interviewees were asked to define inclusive education. As seen in Table 1, the definitions of inclusive education expressed by teacher candidates and mentor teachers fell into two predominant themes: where students are educated (physical placement) or engaging in activities in general education settings (participation). The fieldwork 
supervisors did not separate placement from participation, but defined inclusive practices as consisting of both placement and participation. The IHE Faculty built further upon the definition of inclusive education, noting that inclusive education refers to all students being educated together (placement) and having their needs met (participation).

Teacher Candidates. Teacher candidates predominantly defined inclusive education as consisting of physical placement or student ability to participate in the general education classroom. The responses focused on students with disabilities being placed in a general education classroom and engaging in the same or modified activities. Their descriptions did not include an affective component addressing relationships within the classroom. Likewise, their definitions did not tend to emphasize providing supports and services to enable students to be successful in those general education settings. The essence of their descriptions of inclusive education rested on a technical foundation supported by legal mandates regarding placement and participation of students with disabilities.

$<<$ Insert Table 1 here $>>$

Mentor Teachers. Mentor teachers were also asked to define inclusive education. Physical placement and participation also described the emergent themes from definitions of this group. Similar to teacher candidates, mentor teachers also had a rather superficial and technical understanding of inclusive education as being focused on place and students with disabilities, rather than understanding inclusion as something that is relevant to all students and is greater than geography, but about belonging and meaningful participation and learning. The definitions provided by mentor teachers emphasized placement and participation, rather than meaning or belonging. 
IHE Fieldwork Supervisors. The Praxis Partnership supervisors also were asked to define inclusive education. The supervisors were clinical faculty who organized the program each year, and provided the bulk of the supervision of teacher candidates in their fieldwork placements. IHE fieldwork supervisors took an important first step towards defining inclusive education as beyond placement, and noted that inclusive education must include both physical place and also student participation in the space, rather than the either/or construction of inclusive education seen by teacher candidates and mentor teachers, as depicted in Table 1. These fieldwork supervisors also defined inclusion as applicable to students with disabilities, rather than to all students and all constructs of diversity.

IHE Faculty. The IHE faculty defined inclusive education as encompassing three important elements: all students (not limited to students with disabilities), in a shared physical placement, having their needs met. Within these responses there is a glimmer of hope for reframing the teacher preparation model. Specifically, the faculty interviewed view inclusive education as a social justice issue rather than simply a technical practice or legal requirement. This type of framework may prove useful in moving inclusive practices forward for more students.

\section{Implementing Inclusive education}

Interviewees were then asked to provide an example of inclusive education as they defined it being implemented; either in their own classrooms or in a classroom they had visited. Themes are presented for each group interviewed, as well as exemplar quotes, in Table 2. 
Teacher Candidates. Teacher candidates provided examples of inclusive education that fell into two broad themes, as seen in Table 2. These themes included non-examples (mainstreaming) and discussions of their lack of opportunity to witness inclusive education as they had defined it. The responses of these teacher candidates clearly illustrate that (1) there are on-going concerns about defining inclusive education more similarly to mainstreaming (visiting classrooms for parts of the school day), leading teacher candidates to believe that episodes of mainstreaming were examples of implementing inclusive education, and (2) the teacher candidates had limited exposure to quality inclusive education in their fieldwork settings.

Mentor Teachers. Mentor teachers were also asked to provide examples of implementing inclusive education. The examples from this group included discussions of teacher certification issues, clustering or tracking of students, deficit orientations of students, and accepting students with disabilities as part of the classroom. In essence, rather than describing how they were able to model the implementation of quality inclusive practices to teacher candidates, these mentor teachers predominately discussed various reasons why, in their opinions, it was not possible in their current situations to implement quality inclusive practices. For example, mentor teachers focused on the severity of student disabilities, time and resources issues in general education classrooms. In those instances when mentor teachers felt a student was successfully included, the teachers focused on the affective component of inclusion (having friends and feeling a sense of belonging). It was not clear from these mentor teachers what supports were in place to support students and teachers to make this inclusion possible and successful. 
IHE Supervisors. The Praxis partnership supervisors also provided examples of inclusive education in their interview responses. Their responses fell into three broad themes, including place, exclusion of some students, and school climate. Both of these supervisors noted the new mandate to "include" students in the host district by hiring dually certified teachers, while acknowledging that inclusion was still only available to students with some disabilities and not for others. Interestingly, another example of implementing inclusion focusing on the positive affect of a school as a whole was provided. Again, this example of inclusive education did not specify how this was created or sustained. Both mentor teachers and university supervisors, then, provided examples of inclusive education that are almost impossible to operationalize and thus deduce generalizable strategies from.

IHE Faculty. IHE faculty members were asked to provide examples of inclusive education that teacher candidates were provided in the local district. The IHE faculty discussed the lack of true inclusive opportunities in the local area. The faculty definitions were, on the whole, rather pessimistic in noting dissatisfaction with how the local school district was failing to implement inclusive practices for teacher candidates to learn from. Faculty appeared to mock the clustering practices of the school district and the budgetary decisions for implementing "inclusion," while noting that even with these mandates and practices, many students in the school district remained segregated both functionally and practically.

\section{Limitations}

It is important to note the limitations of the present study. First, the sample did not include all of the faculty, mentor teachers, or teacher candidates enrolled in the 
program. It is possible had all members participated, different themes would have emerged. Second, this study is situated in the unique contexts of a rural district that has been undergoing major changes to its special education delivery. It is possible that more urban school districts would encounter different manners of implementing inclusive education, and it is also likely that IHEs in more urban areas will have a wider range of schools to select from when deciding on fieldwork placements. Finally, the school district hosting the teacher candidates was undergoing major reorganization at the time of the study. The school district was calling its efforts "inclusion," yet many important elements of quality inclusive supports and services were not actually in place to support students and teachers in this program.

\section{Discussion}

A review of the interview responses indicates the teacher candidates in this program learned teaching strategies and dispositions towards inclusive education in a school district that was practicing "inclusion" for a specific group of students (those with high incidence disabilities; some students with low-incidence disabilities were mainstreamed, i.e. visitors, for certain activities). The district continued to segregate students with more significant support needs (as per interview responses), and called their practices "inclusive" when in fact the students were simply placed in (some) general education classes without meaningful support or services. These practices that were modeled in the fieldwork placements contrast with the ideals articulated by many of the faculty members, and in the body of research describing effective inclusive practices. For example, many faculty members defined inclusive education as being relevant to all students (e.g., students who are gifted, those who are learning English, and LGBT 
issues). Mentor teachers, on the other hand, readily used deficit and non-people first language when referring to students who they felt could not be included for a variety of academic, behavioral, and personal reasons (e.g., describing a child as a student who can't speak or read, and describing a student who engages in behaviors that may be distracting and thus detrimental to a teacher). However, it is interesting to note the faculty, mentor teachers, and teacher candidates were describing the same fieldwork practices, yet understood it and described it in very different ways, as described next. The interviews with teacher candidates demonstrated a blend of the inclusive philosophies articulated to them from the university, and mainstreaming and segregating practices and philosophies that were implemented throughout their fieldwork experiences. Reviews of the transcripts further reveal many mentor teachers believed their school was implementing inclusive education well, but that there were real barriers to inclusive education these teachers faced. These barriers were acknowledged to a much lesser extent by the teacher candidates, who seemed to either believe inclusive education was being implemented via pullout services, and/or inclusive education was not being implemented at all, according to their definitions of inclusive education. There were consistencies in responses that inclusive education seemed to be contained by frequency of placement within the general education classroom and degree of participation by students with disabilities. Definitions of inclusive education articulated by teacher candidates and mentor teachers broadly conformed to existing practices. Missing from the definitions was a reframing of inclusive education as a practice that is less about physical space, and more about embracing the notion that all students belong, all students can learn, and that "all" really means all. 
Findings revealed a tension between what is advocated and taught by IHE faculty and what is taught, based on actual practice, and advocated in K-12 schools by mentor teachers. This disconnect is likely to be disorienting to teacher candidates, and may contribute to the lack of progress in implementing and reflecting on effective inclusive practices for all students in K-12 settings. In other words, students graduating from teacher preparation programs without a clear and coherent vision of implementing inclusive practices may be less able themselves to advocate for inclusive education in their teaching careers, thus stagnating a broader societal movement towards more high quality inclusive education in K-12 settings.

Furthermore, the school district in this study was shifting to an "inclusive" model to save money. This is a business model placed on education with efficiency as a controlling factor. The move was not articulated as a social justice or research-based practice. As a result of this move to a new special education delivery model, some teachers were laid off, and others had drastic changes made to their teaching duties. There was a sense of stress and discontent in the district as a whole; it is very likely that these general feelings of malaise are associated with special education, inclusive education, and students with disabilities. It was beyond the scope of the present study to determine if these feelings of discontent were translated as hostility, either overt or covert, towards inclusive education and/or towards students with disabilities. As a result, however, of this movement, the teacher candidates completing fieldwork in the district at this time likely heard messages of inclusive education as being more of a problem to teachers, and a disservice to students, than as a valuable practice that benefits students and is reasonable for teachers. 
Similarly to receiving conflicting messages about the value and feasibility of inclusive education, teacher candidates in this sample graduated without practice developing the necessary skills to actually implement inclusive education. Besides lacking in skills, the teacher candidates seem to possess a superficial understanding of inclusive education. Although they demonstrated caring dispositions toward equity for all students, they were unaware of the power structures and perspectives that contributed to exclusionary practices. Messages from mentor teachers reinforced the concept that inclusive education is a technical requirement and its success is measured by time and participation in a general education classroom. Most groups surveyed described inclusive education as consisting of physical placement and participation.

With this definition in mind, inclusive education as placement and participation, it is unsurprising that most teacher candidates and mentor teachers felt their school was in fact successfully implementing inclusive education, as some students with disabilities were in fact being educated in general education settings. Missing from definitions of inclusive education, and from examples of successful implementation of inclusive education, were the important elements of providing meaningful supports (e.g., collaboration, co-teaching, peer tutoring) and services (e.g., accommodations, systematic instruction) in inclusive settings, and students with disabilities being accepted into the general education classroom as valued members rather than visitors. Presumably, then, effective and meaningful inclusive education was rarely modeled in fieldwork settings, as students receiving special education services were placed in classrooms with few supports (in some cases, with no supports) or were segregated in separate classrooms for all or most of the school day. Rather than being taught the myriad of unique skills and 
criticality needed to successfully prepare teachers to work as inclusive education facilitators, it would appear that the fieldwork component of this program prepares teachers to implement mainstreaming and segregated special education services, while possibly gaining a more cynical disposition towards inclusive education.

A clearer message about inclusive education, as well as the opportunity to learn about and critically analyze the processes involved with implementing effective inclusive practices in fieldwork settings, is needed. This suggests that all those involved in preparing educators, including mentor teachers, university fieldwork supervisors, and university faculty have a consistent and knowledgeable message about inclusive education conveyed to teacher candidates. While it is important to vet mentor teachers for their inclusive dispositions and practices, making judgments about who are fit to mentor and who are not can have an exclusionary effect. With a goal to reframe teacher preparation for inclusive education settings, promoting a collaborative process towards inclusive education might be more appropriate. The values of providing a fair and just education for all students can be drawn on to unify mentor teachers, IHE faculty, supervisors, teacher candidates and other stakeholders to fortify the difficult process of advocating for and implementing inclusive learning environments.

\section{Recommendations for Reframing Teacher Preparation for Inclusive Education}

Considering the dearth of inclusive placements that are typically available for IHEs to select from (e.g., Dotger \& Ashby, 2010), the ability to provide a consistent and coherent inclusive education may seem unfeasible. However, there are steps IHEs can take towards this, even when inclusive fieldwork placements are not currently available for teacher candidates. 
Build Collaborative teams. A commitment to preparing teacher candidates for inclusive learning environments requires a practicum environment that is committed to learning about and implementing inclusive practices. IHE faculty and supervisors might have the added responsibility to dialogue with mentor teachers to discuss beliefs and understandings about inclusive education from their personal viewpoints as well as the school and district's positions on inclusive education. This conversation should not be a top down lesson on inclusive education with required goals for the mentor teachers to follow, rather the discussion would be an inquiry to better understand how issues around inclusive education are framed. Some discussion points aimed at that might be included are (a) definitions of inclusive education; (b) inclusive practices; (c) beliefs about all students being a member of a classroom regardless of severity of disability or behavior needs; and (d) support for teacher candidates to implement inclusive practices with a student on her caseload. By engaging in a conversation with potential mentor teachers, a foundation for collaboration is created.

Institutes of higher education benefit from building alliances with mentor teachers, and can use these placements to build local capacity for inclusive practices. IHEs assist mentor teachers in further developing their inclusive education skills by placing fieldwork students who complete assignments in these settings, in that the fieldwork students acts as a model in some cases for the mentor teacher. IHEs can further build capacity by writing letters of support and acknowledgement to school administrators, highlighting the work of these inclusive-oriented mentor teachers and noting that the IHE has sought placement with this teacher specifically due to her professional commitment for and skills in inclusive education. Finally, IHEs can build 
capacity by inviting mentor teachers to workshops and conferences, hosted by the university or otherwise, which are focused on inclusive practices to continue to support the skill development of these host teachers.

Inclusive Placements. By creating professional relationships with mentor teachers, IHE fieldwork supervisors will better be able to place teacher candidates in settings where inclusive education is already practiced, or where there is a willingness to learn to implement inclusive education. As articulated above, this process builds capacity at the local level for inclusive education. Mentor teachers who have relationships with IHE faculty may feel more empowered and supported to continue their work. IHE faculty can support mentor teachers through acknowledging and celebrating their work to school administrators and with local awards, but also by providing technical assistance to these mentor teachers both within and outside of the fieldwork meetings that typically occur between mentor teachers, IHE faculty, and teacher candidates. Lastly, maintaining close and supportive ties with graduates of the IHE program can foster inclusive placements. In other words, university faculty can provide technical assistance and mentorship to beginning teachers who are learning to navigate their teaching professions and to advocate for inclusive practices.

Coursework. The coursework component of teacher education must also convey an unwavering support for inclusive education, build skill capacity, and a critical consciousness for inclusive education. Course content and assignments must be evaluated to determine if the course implies or directs implementation in self-contained special education settings, or if the strategy being taught in the course is taught in the context of inclusive education. For example, literacy instruction may be taught in a 
manner suggesting pullout instruction (e.g, Browder, Ahlgrim-Delzell, Courtade, Gibbs, \& Flowers, 2008) by teaching students to use special education curricula or instructional strategies that require one-to-one instruction in separate settings. Here, it is advocated that all university coursework explicitly teaches students how to implement instruction in general education settings, using evidence-based, systematic instruction. Likewise, university faculty must prepare teacher candidates to develop inclusive dispositions and advocacy skills. These skills can be woven into methods courses, where students learn to teach specific skills (e.g., literacy) in inclusive settings, while examining potential barriers for inclusive practices within the school, community, and/or home. It is crucial that teacher candidates possess the skills for inclusive education and are able to articulate a position that powerfully advocates for inclusive learning. Lastly, university faculty must prepare teacher candidates to critically analyze the practices they encounter in their fieldwork settings, and to determine if these practices are (a) evidence based and (b) promote the full and meaningful inclusive education of all students. When there is a gap in practice, teacher candidates must understand how to advocate for change in a supportive and informative manner. Fieldwork seminars guided by themes that emerge from the students' fieldwork experiences would be ideal settings to deepen understanding and strengthen agency to advocate for inclusive education, and to teach teacher candidates to question "what can I do to act upon this problem?"

\section{Conclusions}

In this research, we have reported on findings from interviews of teacher candidates, mentor teachers, fieldwork supervisors, and university faculty in a dualcertification teacher program. Conflicting and contradictory messages about what 
constitutes inclusive education were articulated, leaving teacher candidates to navigate a fieldwork setting that often demonstrated practices that were contradictory to the values and practices promoted by their faculty.

The results of this interview study reveal that teacher preparation for inclusive education must be reframed in substantial and important ways. First, we must reframe the idea of "inclusive education" from being a special education issue, to an issue of including, supporting, and teaching all students. When inclusive education is viewed as a special education concern, it is too often thought of as an add-on program, a problem for somebody else to take on, or that could be addressed when time and resources permit. Rather, when inclusive education is viewed as a philosophy of understanding and meeting the needs of all learners, it becomes an issue that all teachers can understand and take ownership of. Secondly, we must reframe the definition of inclusive education as constituting how often or how frequently students who need supports or learn in different styles are placed in general education. Instead, we must look for evidence of building relationships to support all students, developing critical inquiry skills to understand the needs of all students, and developing the skills to truly reach and teach all students. 


\section{References}

Adams, M., Bell, L. A., Griffin, P. (1997). Teaching for diversity and social justice. New York, New York: Routledge.

Allday, R.A., Neilsen-Gatti, S., \& Hudson, T.M. (2013). Preparation for inclusive education in teacher education pre-service curricula. Teacher Education and Special Education, 36, 298-311.

Ashby, C. (2012). Disability studies and inclusive teacher preparation: A socially just path for teacher education. Research \& Practice for Persons with Severe Disabilities, 37, 89-99.

Boyle, C., Topping, K., \& Jindal-Snape, D. (2013). Teachers' attitudes towards inclusion in high schools. Teachers and Teaching: Theory and Practice, 19, 527-542. doi: $10.1080 / 01443410.2013 .785061$.

Browder, D., Ahlgrim-Delzell, Lynn, Courtade, G., Gibbs, S., \& Flowers, Claudia. (2008). Evaluation of the effectiveness of an early literacy program for students with significant developmental disabilties. Exceptional Children, 75, 33-52.

Cameron, D.L., \& Cook, B.G. (2007). Attitudes of preservice teachers enrolled in an infusion preparation program regarding planning and accommodations for included students with mental retardation. Education and Training in Developmental Disabilities, 42, 353-363.

Clifford, E.F., \& Green, V.P. (1996). The mentor-protege relationship as a factor in preservice teacher education: A review of the literature. Early Child Development and Care, $125,73-83$. 
Cook, Bryan G. (2002). Inclusive attitudes, strengths, and weaknesses of pre-service general educators enrolled in a curriculum infusion teacher preparation program. Teacher Education and Special Education, 25, 262-277.

Data Accountability Center. (2008). Data Tables for OSEP State Reported Data. July 2012, from http://www.ideadata.org

Dotger, B., \& Ashby, C. (2010). Exposing conditional inclusive ideologies through simulated interactions. Teacher Education and Special Education, 33, 114-130.

Frattura, E., \& Topinka, C. (2006). Theoretical underpinnings of separate educational programs. Education and Urban Society, 38, 327-344.

Gehrke, R.S., \& Cocchiarella, M. (2013). Preservice special and general educators' knowledge of inclusive education. Teacher Education and Special Education, 36, 204-216.

Gut, D.M., Oswald, K., Leal, D.J., Frederiksen, L., \& Gustafson, J.M. (2003). Building the foundations of inclusive education through collaborative teacher preparation: A university-school partnership. College Student Journal, 37, 111-127.

Harvey, M.W., Yssel, N., Bauserman, A.D., \& Merbler, J.B. (2010). Preservice teacher preparation for inclusive education: An exploration of higher education teachertreaining institutions. Remedial and Special Education, 31, 24-33.

Hennissen, P., Crasborn, F., Brouwer, N., Korthhagen, F., \& Bergen, T. (2011). Clarifying pre-service teacher perceptions of mentor teachers' developing use of mentoring skills. Teaching and Teacher Education, 27, 1049-1058.

Individuals with Disabilities Education Improvement Act, H.R. 1350, Pub. L. No. P.L. $108-446$ (2004). 
Kumashiro, K. (2009) Against common sense: Teaching and learning toward social justice. New York, NY: RoutledgeFalmer.

Oyler, C. (2011). Teacher preparation for inclusive and critical (special) education. Teacher Education and Special Education, 34, 201-218.

Scruggs, T., \& Mastropieri, M. (1996). Teacher perceptions of mainstreaming/inclusive education, 1958-1995: A research synthesis. Exceptional Children, 63, 59-74.

Stiker, H.-J. (1997). A history of disability. Ann Arbor: University of Michigan Press.

Strauss, A., \& Corbin, J. (1990). Basics of qualitative research: Grounded theory procedures and techniques. Newbury Park, CA: Sage.

Tompkins, R. \& Deloney, P. (2013). Inclusive education: The pros and cons. Issues... about change, 4(3). Austin, TX: Southwest Educational Development Laboratory. Retrieved from http://www.sedl.org/change/issues/issues43/definition_inclusion.html

Voss, J. \& Bufkin, L.J. (2011). Teaching all children: Preparing early childhood preservice teachers in inclusive settings. Journal of Early Childhood Teacher Education, 32, 338-354.

Young, K.S. (2011). Institutional separation in schools of education: Understanding the functions of space in general and special education teacher preparation. Teaching and Teacher Education, 27, 483-493. 
Table 1: Definitions of Inclusive Education

\begin{tabular}{|c|c|c|}
\hline $\begin{array}{l}\text { Responden } \\
t\end{array}$ & Theme & Exemplar Quotes \\
\hline \multirow[t]{2}{*}{$\begin{array}{l}\text { Teacher } \\
\text { Candidates }\end{array}$} & $\begin{array}{l}\text { Physical } \\
\text { Placement }\end{array}$ & $\begin{array}{l}\text { "Bringing those that have disabilities within the classroom" } \\
\text { "Being in the gen ed classroom as much as possible. Pushing in services when needed." } \\
\text { "Having students with disabilities in the classroom all day every day, so, versus getting } \\
\text { pulled out." }\end{array}$ \\
\hline & $\begin{array}{l}\text { Participatio } \\
n\end{array}$ & $\begin{array}{l}\text { "Any and all amount of time that all abilities of students are working together" } \\
\text { "Individual being as involved in a general ed classroom as possible" } \\
\text { "Those students are getting the modifications and accommodations to be in the general } \\
\text { population for what they can handle..." } \\
\text { "If that requires an adult aide or something that that is done [so] they're still being } \\
\text { involved." }\end{array}$ \\
\hline \multirow[t]{2}{*}{$\begin{array}{l}\text { Mentor } \\
\text { Teachers }\end{array}$} & $\begin{array}{l}\text { Physical } \\
\text { Placement }\end{array}$ & $\begin{array}{l}\text { "Having children with [individual education programs] or identified special needs in a } \\
\text { quote unquote regular classroom. So that they have typically developing peers around." } \\
\text { "All students are placed in a general education classroom and are only pulled out of the } \\
\text { classroom to receive services that cannot be administered in the general education } \\
\text { classroom." }\end{array}$ \\
\hline & $\begin{array}{l}\text { Participatio } \\
n\end{array}$ & $\begin{array}{l}\text { "for students to be exposed to and participate in the mainstream curriculum" } \\
\text { "If I were to describe it to someone else, it would be to incorporate the special ed student } \\
\text { into the general education classroom as much as possible." }\end{array}$ \\
\hline
\end{tabular}




\begin{tabular}{|l|l|l|}
\hline $\begin{array}{l}\text { University } \\
\text { Supervisor }\end{array}$ & $\begin{array}{l}\text { Place and } \\
\text { Participatio } \\
\text { n }\end{array}$ & $\begin{array}{l}\text { "Inclusion would be when a child with a disability is both placed physically with typical } \\
\text { peers as well as receives all educational services with typical peers - in the classroom and } \\
\text { alongside peers." }\end{array}$ \\
$\begin{array}{l}\text { University } \\
\text { Faculty }\end{array}$ & $\begin{array}{l}\text { All Students, } \\
\text { Place, } \\
\text { and } \\
\text { Participatio } \\
\text { n }\end{array}$ & $\begin{array}{l}\text { "All students regardless of their needs are included into a classroom setting at whatever } \\
\text { level they can perform at. I think that's for both ends of the spectrum. Both gifted and } \\
\text { those that might need accommodations. I think all students should have that experience." } \\
\text { "I have to think of diversity, social justice, and trying to create an inclusive environment } \\
\text { not just of academic ability, but also look at hidden biases towards gender, LGBT" }\end{array}$ \\
\hline
\end{tabular}


Table 2: Examples of Implementing Inclusive Education

\begin{tabular}{|c|c|c|}
\hline $\begin{array}{l}\text { Responden } \\
t\end{array}$ & Theme & Exemplar Quotes \\
\hline \multirow[t]{2}{*}{$\begin{array}{l}\text { Teacher } \\
\text { Candidates }\end{array}$} & $\begin{array}{l}\text { Mainstreamin } \\
\mathrm{g}\end{array}$ & $\begin{array}{l}\text { "at [elementary school] I don't know that I saw kids being pulled out a ton for resource } \\
\text { type classrooms." } \\
\text { "it was not very stigmatizing, they got pulled out constantly but it didn't seem like the } \\
\text { students were thinking, oh, that child is going to get tested... they did a lot of ability } \\
\text { grouping" } \\
\text { "A lot of the time, they were in a self-contained classroom doing core subjects other } \\
\text { than being science...[they were included] in particular subject areas like PE and } \\
\text { specials" } \\
\text { "Everyday, [the behavior support class] had their inclusion times where, during } \\
\text { science they would get to go up to the general education or during specials they were } \\
\text { with the rest of their grade level" }\end{array}$ \\
\hline & $\begin{array}{l}\text { No Experience } \\
\text { with Inclusive } \\
\text { Education }\end{array}$ & $\begin{array}{l}\text { "I never saw any of the students who were in the low-incidence classrooms being } \\
\text { included" } \\
\text { "I don't feel like any schools thus far have done it enough...The teachers don't, the gen } \\
\text { ed teachers don't really include them as far as participating. [The students] kind of } \\
\text { just sit there with their para-pro, not doing a whole lot" }\end{array}$ \\
\hline \multirow[t]{2}{*}{$\begin{array}{l}\text { Mentor } \\
\text { Teachers }\end{array}$} & $\begin{array}{l}\text { Teacher } \\
\text { Certification } \\
\text { Issues }\end{array}$ & $\begin{array}{l}\text { "We don't have an special ed teacher this year. All kids on [individual education } \\
\text { programs] are fully included... we are really strong with the [response to } \\
\text { intervention]" } \\
\text { "It's impossible for her [dual-cert teacher] to teach her class and to do the minutes } \\
\text { [special ed services] at the same time. So I think the inclusion piece has been put } \\
\text { heavier on the gen ed teacher because of what's going on right now." }\end{array}$ \\
\hline & Clustering / & "We have a special ed [certified] person at each grade level. And they have most of the \\
\hline
\end{tabular}




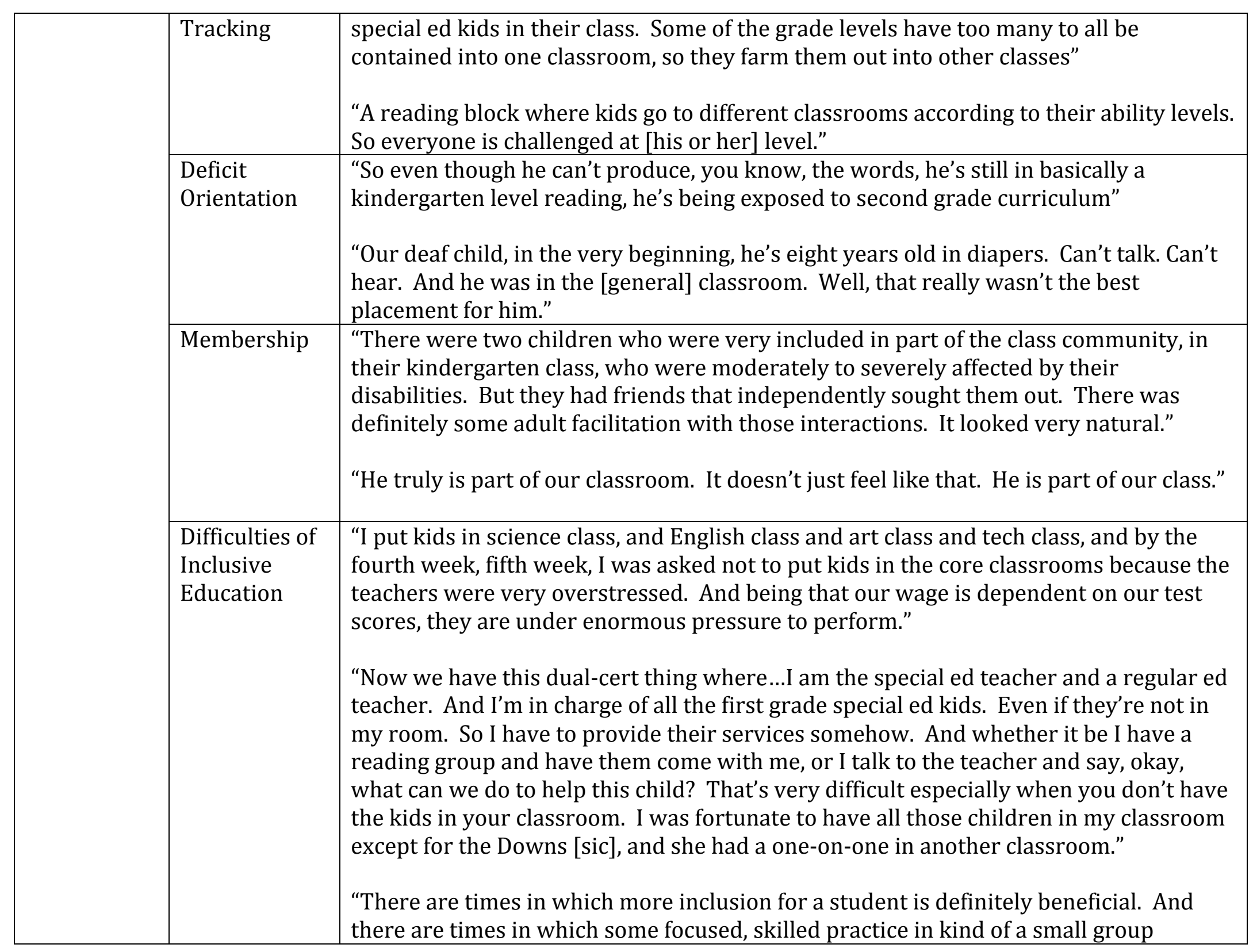




\begin{tabular}{|c|c|c|}
\hline & & $\begin{array}{l}\text { environment is really going to be most beneficial" } \\
\text { "But being in the real world, I think especially when test scores are a huge focus for } \\
\text { general classrooms, and having kids that you know, throw things, bite themselves, hit } \\
\text { other kids, which is a lot of what my kids do, it's very distracting." }\end{array}$ \\
\hline \multirow[t]{3}{*}{$\begin{array}{l}\text { University } \\
\text { Supervisors }\end{array}$} & Place & $\begin{array}{l}\text { "Schools are mandated to have inclusive practices...one special ed, elementary ed } \\
\text { teacher per grade level, who will do case managing and teaching" } \\
\text { "[School District] is trying to go the inclusionary route, you know, using dually } \\
\text { certified teachers... Doing more push in than pull out kind of services" }\end{array}$ \\
\hline & Exclusion & $\begin{array}{l}\text { "But again, when we have individuals with more severe disabilities, there's more of a } \\
\text { containment, I think at any school" }\end{array}$ \\
\hline & $\begin{array}{l}\text { School } \\
\text { Climate }\end{array}$ & $\begin{array}{l}\text { "[Alternative schools] embrace all students, and it's not a fully restricted [like a private } \\
\text { placement]..but to me it's restrictive in the sense that the majority of the students } \\
\text { there are students with IEPs versus not... So they're not inclusive in terms of the } \\
\text { population, but they're inclusive from the climate of the school" }\end{array}$ \\
\hline $\begin{array}{l}\text { University } \\
\text { Faculty }\end{array}$ & $\begin{array}{l}\text { Lack of } \\
\text { Inclusive } \\
\text { Experiences } \\
\text { in Local Area }\end{array}$ & $\begin{array}{l}\text { "'They've created low tracks. Low, medium, and high tracks...And I know a teacher } \\
\text { there who had all the special education students clustered... So they've clustered 'em. } \\
\text { And, they're throwing in the ELLs with them, and creating a track. And so, but for me } \\
\text { that's not inclusion because that's not your community...It's a restrictive } \\
\text { environment..." } \\
\text { "All the schools say they honor diversity, and all the schools say they honor inclusion. } \\
\text { I have not seen any school [in this district] that does that." } \\
\text { "Policy being, we're going to force inclusion for budgetary purposes ...to affect the } \\
\text { number of faculty we have on staff. So fewer self-contained and pullout special } \\
\text { education classrooms, and more inclusion classrooms. Except for those students who } \\
\text { have more significant cognitive or behavioral needs." } \\
\text { "The schools in [this district] practice mainstreaming, for some students who earn it } \\
\text { (laughs), and call it inclusion." }\end{array}$ \\
\hline
\end{tabular}


